\title{
УДК 342.5
}

DOI https://doi.org/10.32840/1813-338X-2019-3-2

\section{О. Ю. Дудченко}

кандидат юридичних наук, асистент кафредри судоустрою та прокурорської діяльності Національного юридичного університету імені Ярослава Мудрого

\section{ТЕОРЕТИЧНІ ПЕРЕДУМОВИ ДОСЛІДЖЕННЯ ДЕРЖАВНОЇ ВЛАДИ}

Стаття присвячена вивченню теоретичних передумов дослідження держави та державної влади. Зроблена спроба встановити джерела походження державної влади.

У статті зазначено, що дослідження френомену влади, а також пошук найефективнішої форми ї̈ реалізації можна віднести до фундаментальних питань юридичної науки, яке вивчалося вченими всіх часів. Проблеми державної влади були предметом аналізу багатьох мислителів давнини. Проаналізовано підходи до розуміння держави та державної влади такими мислителями, як Т. Гоббс, Д. Фільмер, Святий Августин, Фома Аквінський.

Звертається увага на визначення самого поняття «влада», зазначено, що у зв'язку з різноманітністю його тлумачень воно є багатоаспектним. Так, у літературі можна зустріти роздуми про владу випадковості, про владу над природою, про владу об'єктивних природних і суспільних закономірностей, про господарську або економічну владу, про владу соціальну, політичну або державну тощо. У зв'язку з таким широким тлумаченням і неоднозначним наповненням змістовною інтерпретацією поняття «влада» запропоновано його найпростіше визначення, яке зводиться до психологічного впливу одного суб'єкта (котрий реалізує владу) на іншого (який у цьому взаємовідношенні виступає як об'єкт владного впливу).

Автор торкається питання структури влади, яка фоормується з розгалуженої мережі бюрократичних, військових, дипломатичних, економічних, політичних, правових і фрінансових інституцій.

Встановлено, що державна влада є первинною щодо всіх інших видів управління, оскільки навіть там, де держава за зовнішніми ознаками залишає владу певних людських об'єднань непошкодженою, вона, тим не менш, привласнює ії собі в такій фрормі, що визнає себе ії джерелом. Це проявляється в тому, що держава присвоює собі право нормувати своїм законодавством будь-яку пануючу владу в межах своєї території. Сучасна держава визнає за кожним індивідом і кожним союзом визначену законом сфреру свободи від державної влади, але визнати самостійну пануючу владу, яка протистояла б державі як нездоланна межа їі влади, вона не може за самою своєю суттю.

Ключові слова: держава, влада, структура влади, функкії влади.

Постановка проблеми. У юридичній науці питання про державу і владу, а також їхню сутність $€$ центральним. Державу можна розглядати як союз людей, які осіли в певних межах і підпорядковані одній владі, або як корпорацію народу, що населяє певну територію, причому ця корпорація володіє первинною верховною владою. 3 цього погляду держава складається 3 трьох елементів: влада, населення і території. Від розуміння сутності держави та державної влади залежить постановка і рішення інших основних питань - про функції держави, про державний механізм, про державні органи тощо.

Останнім часом дослідження влади перейшло на інший рівень. 3 цього приводу філософ
В.Г. Ледяєв зазначає, що, позбавившись тоталітарних кайданів, соціальна наука та масова свідомість пострадянських суспільств швидко перебороли минулий дисбаланс між важливістю феномену влади й обсягом його наукового дослідження, втім, недостатня увага до концептуальних питань вказаного явища призводить до того, що під владою, у її соціальному вимірі, почали розуміти будь-які події та явища, пов'язані зі здійсненням впливу одних людей на інших, а також зі сферою політики загалом [5, с. 100]. У наукових джерелах владу сьогодні ототожнюють 3 «авторитетом», «впливом», «пакуванням», «примусом», «силою», «управлінням» тощо. 
Аналіз останніх досліджень і публікацій. Дослідження френомену влади, а також пошук найефективнішої фрорми її реалізації можна віднести до фундаментальних питань юридичної науки, яке вивчалося вченими всіх часів. Невипадково проблеми державної влади були предметом розгляду багатьох мислителів давнини (Аристотеля, Платона, Сократа, Цицерона та ін.). Так, англійський фрілософр-матеріаліст XVII ст. Томас Гоббс у межах свого фрілософського вчення зазначав, що з усіх наук найбільш шанованою наукою виявляється та, яка важлива для правителів та інших людей, котрі здійснюють управління родом людським. Користь такої науки, якщо вона викладена коректно, тобто виведена з очевидною необхідністю та з правильних принципів, краще за всіх зрозуміємо лише тоді, коли розглянемо, яка шкода трапляється для роду людського з хибного розуміння іiї, що зводиться лише до марнослів'я [3, с. 276]. На думку Т. Гоббса, правильне навчання громадян науці про державу необхідне для збереження миру, тому обов'язком правителів $є$ здійснення кодифікації основних положень істинного громадянського (цивільного) вчення та введення обов'язкового викладання їх у всіх університетах держави. Т. Гоббс зазначав, що всі обов'язки правителів можна висловити однією фразою: благо народу - вищий закон [3, с. 276-277].

Проблематика державної влади, а також ії ознак розглядається в історії щоразу під різними кутами зору, залежно від конкретно-історичних інтересів, потреб, завдань і цілей, що виникали в суспільстві у відповідний історичний період. Однак необхідно зазначити, що таке дослідження в будь-який період здійснювалося в тісному взаємозв'язку з дослідженням феномену держави.

Мета статті - вивчити теоретичні передумови дослідження державної влади та держави. Встановити джерела її походження.

Виклад основного матеріалу. Стосовно того, що таке держава і яке їі походження, в наукових джерелах $є$ безліч міркувань. Так, відповідно до патріархальної теорії походження держава - це сім'я, яка розрослася, а державна влада - це влада батька у сім'ї. 3 цього приводу Т.В. Чехович зазначає, що таке просте визначення державної влади та держави, попри його простоту, відігравало в деякі історичні періоди чималу політичну роль [6, с. 12]. Спираючись на вказану концепцію, Джон Фільмер у сере- дині XVII ст. здійснював захист права англійського короля на державну владу, вказуючи, що як не можна стратити свого рідного батька, так само не можна стратити й короля, який також $€$ батьком для свого народу. Подібний підхід був характерним для різноманітних політичних доктрин, спрямованих на захист фооми самодержавства.

Починаючи з IV - V ст. більшість досліджень приділено богословській теорії походження держави та державної влади. Так, Святий Августин стверджував, що земна держава - це тільки погане відображення божественної держави. Він негативно ставився до юристів, які в своїй більшості підтримували позицію природноправової теорії походження держави. I лише у XIII ст. Фома Аквінський, визнаючи реальність і важливість світської держави, а також державної влади, разом із пануванням закону Божого визнав право юристів на їх громадську діяльність, що не заважає захисту божественного та природного права.

Стосовно самого поняття «влада», то у зв'язку з різноманітністю його тлумачень воно $€$ багатоаспектним. У літературі можна зустріти роздуми про владу випадковості, про владу над природою, про владу об'єктивних природних і суспільних закономірностей, про господарську або економічну владу, про владу соціальну, політичну або державну тощо. У зв'язку з таким широким тлумаченням і неоднозначним наповненням змістовною інтерпретацією поняття «влада» набуває неабиякої кількості значень і втрачає свою точність [6, с. 12]. Це змушує фрормалізувати поняття «влада» і «державна влада», оскільки це пов'язано з певним колом питань змістовного характеру, що зумовлюється трактуванням деяких положень (наприклад, обсягу повноважень правоохоронних державних органів, розмежування і взаємодії органів, що входять до правоохоронної системи, тощо).

Найпростіше визначення влади зводиться до психологічного впливу одного суб'єкта (котрий реалізує владу) на іншого (який у цьому владному взаємовідношенні виступає як об'єкт владного впливу).

Структура влади $€$ надзвичайно складною. Вона формується з розгалуженої мережі бюрократичних, військових, дипломатичних, економічних, політичних, правових і фінансових інституцій. До суб'єктів здійснення влади належать соціальні спільноти, індивіди, рухи й організації держави, а також їх складники. 
На інституційному макросистемному рівні Т.В. Чехович до суб'єктів влади відносить структуровані гілки державної влади, інститути глави держави, омбудсмена, політичні партії, групи тиску, політичну опозицію тощо [6, с. 23]. На її думку, соціальна система влади як цілісність містить ряд підсистем - правову, адміністративно-управлінську, військову, виховно-освітню тощо, де як горизонтально, так і вертикально встановлюються характерні для кожної з підсистем відносини. Влада - це першочергова умова реалізації права, що $є$ наріжним каменем існування держави. Водночас вона підпорядковується праву, яке покликане чітко визначити владні прерогативи та функції держави. Враховуючи це, можна стверджувати, що влада - це своєрідна система комунікацій, яка розкривається на різних рівнях: між двома чи більше суб'єктами, між суб'єктами й об'єктами, між двома чи більше особами чи сторонами, що беруть участь у системі владних відносин $[6$, c. 23].

Як зазначав Талкотт Парсонс, влада посідає в аналізі політичних систем місце, подібне до того, яке належить грошам в економічних системax [4, с. 60]. Також, як справедливо зауважив Карл Дойч, вона $є$ одним із «засобів розрахунку» в політиці, який застосовується там, де не спрацьовує вплив на сторони або добровільне погодження дій. Влада виконує функції врегулювання групових конфліктів і здійснення комунікації всередині системи [2, с. 61].

У цьому контексті Т.В. Чехович визначає основні соціальні функції влади в політичній системі:

- інтегративну, тобто об'єднання всіх соціальних сил, політичних, матеріальних та інтелектуальних ресурсів і підпорядкування їх політичним, суспільно важливим цілям;

- мотивувальну - формування мотивів політичної діяльності, підпорядкування їм інших мотивів та інтересів;

- соціального контролю - забезпечення належного контролю з метою підтримання легітимності держави;

- регулятивну - спрямування волі суб'єктів політичних відносин на створення політичних механізмів регулювання життєдіяльності суспільства;

- об'єднувальну (консолідуючу) - політичне та юридичне забезпечення участі у формуванні та функціонуванні органів усіх інститутів політичної системи;
- репресивну - підтримання існуючого правопорядку та політичного ладу, дотримання політичних і правових норм;

- стабілізуючу - сприяння стійкому розвитку суспільства та всіх структур його політичної системи [6, с. 24].

Особливу позицію в дослідженні влади займає німецький соціолог Макс Вебер, котрий розрізняє поняття влади та панування. Він відштовхується від положення, запропонованого Монтеск'є, згідно з яким основним у понятті влади виступає не те, одній чи кільком особам вона належить, а те, як ця влада здійснюється у практичному житті, а саме чи з додержанням законів і почуттям міри чи, навпаки, зі свавіллям і насильством. Таким чином, Вебер вказував, що влада зумовлена шансом діючої особи нав'язати свою особисту волю іншому індивідові, навіть у разі протидії з боку останнього. На думку М. Вебера, влада - це внутрішній фрактор суспільного зв'язку, який вказує на наявність нерівності. Стосовно панування, то воно обов'язково передбачає наявність пана, у котрого $є$ шанс розраховувати на підлеглість тих осіб, які теоретично повинні йому підкорятися. Різниця між владою та пануванням полягає у тому, що у першому випадку наказ не $є$ законною необхідністю, а підкорення не завжди є обов'язком, тоді як у другому випадку підкореність заснована на визнанні наказів тими, хто їм підкоряється [1, с. 31].

Слід зазначити, що будь-яка цільова людська єдність потребує керівництва єдиною волею. Волею, метою якої $€$ піклування про спільні інтереси цієї єдності, що може наказувати та змушувати виконувати накази. Будьяке, навіть найбільш хитке об'єднання має свою особливу, відповідну його характеру владу.

$€$ два види союзної влади: панівна і не панівна. Не панівна союзна влада характеризується тим, що вона може видавати обов'язкові постанови для членів об'єднання, але не в змозі власними силами та засобами примусити до виконання ії̈ наказів. Член будь-якого об'єднання, в основі якого лежить не панівна влада, може в будь-який час піти. Для того, щоб утримати його в об'єднанні або щоб примусити його, незважаючи на бажання вийти з об'єднання, виконувати щодо останнього необхідні за статутом обов'язки, необхідне волевиявлення або вплив будь-якої сили, що стоїть над об'єднанням. Це стосується всіх об'єднань, в основі яких не панівна влада, а не тільки тих, 
у які вступають добровільно. Найбільш чітко це проявляється в положенні, що займає одне 3 найбільших недержавних об'єднань - церква (щодо ії членів). Хоча влада церкви над ії членами $є$ значною, однак юридично вона не володіє пануванням, хіба що держава надає їй підтримку.

Наскільки $б$ широко не розвинула систему своїх впливів проста союзна влада, у членах об'єднання, що вільно підкоряються ії волі, вона знаходить межу можливого для неї самостійного втілення. Вона може встановити цілу систему правил для членів союзу, вдаватися до каральних норм, але того, хто не хоче підкоритися цьому праву і цим покаранням, союз примусити не може. Засоби, якими союз наділений у своєму розпорядженні для санкціонування своїх наказів, мають виключно дисциплінарний характер. Влада такого союзу - влада дисциплінарна, а не державна.

Така дисциплінарна влада реалізується у значній кількості приватних відносин між окремими особами. Вона існує всюди, де встановлені триваючі правовідносини. Для регулювання цих відношень, для їх зміцнення, іншими словами - для охорони порядку, уповноважена сторона може робити зауваження, встановлювати та приводити у виконання інші стягнення. Але крайнім i найтяжчим дисциплінарним засобом $€$ припинення особистого становища, виключення з об'єднання. Незважаючи на цю дисциплінарну владу, підлеглий їй може в будьякий час вийти із союзу.

I навпаки, панівна влада $є$ владою, що не терпить опору. Владарювати - значить керувати і бути в змозі примушувати до виконання. Від будь-якої влади підлеглий може ухилитися, але тільки не від влади панівної. Будь-який інший союз може виключити члена, союз панівний може в силу своєї первісної влади утримати його в союзі. Необхідно наголосити, що $з$ держави можливий тільки умовний вихід, з умовою, що особа підкорилася іншій державі. Влада, наділена такою силою, $є$ владою панівною, тобто державною. Панування $є$ тим критерієм, який відрізняє державну владу від всіх інших влад. У тих випадках, де ми знаходимо таку пануючу владу у будь-якого союзу або індивіда, що входить до складу держави, вона виходить від державної влади, тобто вона не первинна, а похідна.

Варто зауважити, що це положення відповідає відносинам сучасної держави. До консоліда- ції держави його не існувало. Воно є історичною, а не абсолютною категорією для кваліфрікації панівних об'єднань. У середні віки існували численні союзи недержавного характеру, які здійснювали в тому чи іншому обсязі панування як початкове своє право. Насамперед мала самостійну владу церква, котра нерідко з успіхом використовувала цю владу проти держави. Так само численні союзи та феодальні власники здійснювали панування, яке вони розглядали як своє власне. Вже з однієї цієї причини навряд чи можливо за допомогою сучасних державно-правових понять провести в тодішньому політичному світі сувору межу між державою і недержавним союзом. Але посилення державної влади в боротьбі з обмежуючими та протидіючими силами призводить до поглинання самостійної влади державою. Підтвердженням цього $€$ судження Т. Гоббса, котрий визначав державу як біблійне чудовисько, Левіафана, що підкоряє собі все навкруги. Однак люди самі уклали договір про своє повне підкорення Левіафрану, віддали йому всі свої права, оскільки до цього в природному існуванні людей домінував принцип «людина людині - вовк» [3, с. 158]. Дещо схоже появу державної влади пояснює Ж.Ж. Руссо, який зазначав, що державна влада виникла на підставі складання громадського договору, і відповідно до нього кожен віддав державі частку своєї незалежності, самостійності й одержав від неї необхідну охорону стосовно свого існування як громадянина в межах відповідної держави.

Висновки і пропозиції. На нашу думку, державна влада $€$ первинною щодо «громадських договорів» Гоббса та Руссо, оскільки навіть там, де держава за зовнішніми ознаками залишає владу певних людських об'єднань не пошкодженою, вона привласнює ії собі в такій формі, що визнає себе ії̈ джерелом. Це проявляється в тому, що держава присвоює собі право нормувати своїм законодавством будь-яку пануючу владу в межах своєї території. Сучасна держава визнає за кожним індивідом і кожним союзом визначену законом сферу свободи від державної влади, але визнати самостійну пануючу владу, яка протистояла б державі як нездоланна межа її влади, не може за самою своєю суттю.

\section{Список використаної літератури:}

1. Витченко А.М. Теоретические проблемы исследования государственной власти. Саратов : Изд-во Саратовского ун-та, 1982. 194 с. 
2. Гаджиев К.С. Введение в политическую науку : учебник. Москва : Логос, 2000. 540 с.

3. Гоббс Т. Основы фрилософрии : Сочинения в 2 т. Москва : Мысль, 1989. Т. 1. Ч. 3. О гражданине. 621 с.

4. Гомеров И.Н. Государство и государственная власть: предпосылки, особенности, структура. Москва : ЮКЭА, 2002. 830 с.
5. Ледяев В.Г. Власть: концептуальный анализ. Москва : РОССПЭН, 2001. 380 с.

6. Чехович Т.В. Державна влада як інститут конституційного права України : дис. ... канд. юрид. наук : 12.00.02 / Київський національний університет імені Тараса Шевченка. Київ, 2005. $218 \mathrm{c}$.

Dudchenko A. Yu. Theoretical prerequisites of the research of the governmental authority

The research of theoretical prerequisites of the study of the state and governmental authority are considered in the article. An attempt to establish the sources of origin of governmental authority is made in the article. The article states that the study of the phenomenon of authority, as well as the search for the most effective form of its implementation, can be attributed to fundamental questions of legal science, which has been studied by scientists at all times. Problems of governmental authority have been the subject of research by many thinkers of antiquity. The approaches to understanding the state and governmental authority by such researchers as T. Hobbs, D. Filmer, St. Augustine, Thomas Aquinas, etc. are analyzed.

Attention is drawn to the definition of the term "authority" itself, it is stated that it is multidimensional due to the variety of its interpretations. Considerations on the authority of chance, authority over nature, the authority of objective natural and social laws, economic or economic authority, the authority of social, political or governmental etc. can be found in literature. In connection with such a broad interpretation and ambiguous filling of a meaningful interpretation of the concept of "authority" its simplest definition is proposed, which boils down to the psychological influence of one subject (exercising authority) on another (which in this power relation acts as an object of authority influence). The issue of the structure of government, which is formed from an extensive network of bureaucratic, military, diplomatic, economic, political, legal and financial institutions is considered in the article.

It is established that governmental authority is primary in relation to all other types of government, since even where the state externally leaves the power of certain human associations not damaged, it nevertheless appropriates it in a form that recognizes it source. This is manifested in the fact that the state reserves the right to regulate with its legislation any dominant power within its territory. The modern state, although recognizing for every individual and every union the sphere of freedom from state power defined by law, but recognizing an independent dominant power that would resist the state as an insurmountable boundary of its power, it cannot by its essence.

Key words: state, authority, structure of authority, functions of authority. 